\title{
Experimental and Numerical
}

Analysis of Gypsum Plasterboards in Fire

\section{Journal Article}

Author(s):

Frangi, Andrea; Schleifer, Vanessa; Fontana, Mario; Hugi, Erich

Publication date:

2010

Permanent link:

https://doi.org/10.3929/ethz-b-000017431

Rights / license:

In Copyright - Non-Commercial Use Permitted

Originally published in:

Fire Technology 46(1), https://doi.org/10.1007/s10694-009-0097-5 


\title{
Experimental and Numerical Analysis of Gypsum Plasterboards in Fire
}

\author{
Andrea Frangi*, Vanessa Schleifer and Mario Fontana, Institute of Structural \\ Engineering, ETH Zurich, 8093 Zurich, Switzerland \\ e-mail: schleifer@ibk.baug.ethz.ch;fontana@ibk.baug.ethz.ch
}

Erich Hugi, Empa, Swiss Laboratories for Materials Testing and Research, 8600 Duebendorf, Switzerland e-mail: erich.hugi@empa.ch

Received: 27 September 2008/Accepted: 20 March 2009

\begin{abstract}
The fire performance of light timber frame assemblies mainly depends on the protection provided by the cladding. A comprehensive experimental and numerical analysis on the fire behaviour of protective cladding made of gypsum plasterboards and wood-based panels has been recently carried out at ETH Zurich. The paper describes the main results of the experimental and numerical analyses carried out with gypsum plasterboards. The results of the experimental and numerical analysis allowed the development of a design model for the verification of the separating function (insulation and integrity criteria) of light timber frame wall-and-floor assemblies.
\end{abstract}

Keywords: fire tests, gypsum plasterboards, numerical analysis, start of charring, insulation value

\section{Introduction}

Light timber frame wall-and-floor assemblies are typical structural elements used in timber engineering. The assemblies consist of solid timber studs or beams with cladding made of gypsum plasterboards, wood-based panels or combinations of these layers. The cavities may be filled with insulation made of rock, glass or wood fibre. Unlike heavy timber structures in which the char-layer of fire-exposed members performs as an effective protection of the remaining unburned residual crosssection, the fire performance of load-bearing and non load-bearing light timber frame assemblies mainly depends on the protection provided by the cladding [1-3].

In order to limit fire spread by guaranteeing adequate fire compartmentation, elements forming the boundaries of fire compartments are designed and constructed in such a way that they maintain their separating function during the relevant fire exposure (requirement on insulation I and integrity E). The required period of time is normally expressed in terms of fire resistance using the ISO fire exposure [4] and is specified by the building regulations. While fire tests are still widely used for the verification of the separating function of light timber frame assemblies, design models are becoming increasingly common.

\footnotetext{
* Correspondence should be addressed to: Andrea Frangi, E-mail: frangi@ibk.baug.ethz.ch
} 
In timber buildings, walls and floors are mostly built up by adding different layers to form an assembly. For the verification of the separation function of timber assemblies, component additive methods are common. These models are called component additive models, since the fire resistance of a layered construction is obtained by adding the contribution to the fire resistance of the different layers. In [5] calculation models for the verification of the separating function of light timber frame wall-and-floor assemblies used in the UK [6], North America [7] and Sweden [8,9] as well as according to ENV 1995-1-2 [10] have been presented and reviewed. The current design method according to EN 1995-1-2 (Annex E) [11] is based on the Swedish component additive method. As an enhancement of the method of ENV 1995-1-2 and the North American method, the Swedish component additive method takes into account the influence of adjacent materials on the fire performance of each layer and therefore describes the real fire performance more appropriately. However, the design method is based on input data that was deduced from a limited number of fire tests on wall assemblies and therefore only covers a limited range of timber structures.

A comprehensive research project on the separating function of light timber frame wall-and-floor assemblies with cladding made of gypsum plasterboards and wood-based panels has been carried out at ETH Zurich in collaboration with the Swiss Laboratories for Materials Testing and Research (EMPA). The objective of the research project was the development of an improved design model for the verification of the separating function (insulation and integrity criteria) of light timber frame wall-and-floor assemblies. A large number of small-scale fire tests permitted the analysis of different parameters (material, thickness, position and number of the cladding layers) on the thermal behaviour of protective cladding made of gypsum plasterboards and wood-based panels [12]. The results of the fire tests allowed the verification and calibration of thermal properties used for thermal finite element (FE) analysis. Based on an extensive FE parametric study, the coefficients of the design model for the verification of the separating function of light timber frame wall-and-floor assemblies were calculated. The design model was verified by means of full-scale fire tests.

The paper first describes the basic idea of the design model for the verification of the separating function of light timber frame wall-and-floor assemblies. Then, the main results of experimental and numerical analyses on gypsum plasterboards are presented. The results enlarge the knowledge of the fire behaviour of gypsum plasterboard and permitted the calculation of the coefficients of the design model for the verification of the separating function of light timber frame wall-and-floor assemblies.

\section{Design Model for the Verification of the Separating Function}

The developed design model for the verification of the separating function of light timber frame wall-and-floor assemblies is based on the additive component method given in EN 1995-1-2. The developed model is capable of handling timber 
assemblies with an unlimited number of layers made of gypsum plasterboards, wood panels or combinations of both. The cavity may be void or filled with insulation consisting of rock or glass wool.

The total fire resistance is taken as the sum of the contributions from the different layers (claddings, void or insulated cavities):

$$
\mathrm{t}_{\text {ins }}=\sum \mathrm{t}_{\text {prot }, \mathrm{i}-1}+\mathrm{t}_{\text {ins }, \mathrm{i}}
$$

with $\sum t_{\text {proti-1 }}$, sum of the protection values of the layers (in direction of the heat flux) preceding the last layer of the assembly on the fire-unexposed side [min]; $t_{\text {ins, },}$, insulation value of the last layer of the assembly on the fire-unexposed side [min].

Protection and insulation values of the layers can be calculated according to following general equations taking into account the basic values of the layers, the coefficients for the position of the layers in the assembly and the coefficients for the joint configurations:

$$
\begin{aligned}
& \mathrm{t}_{\text {prot }, \mathrm{i}}=\left(\mathrm{t}_{\text {prot }, 0, \mathrm{i}} \cdot \mathrm{k}_{\text {pos }, \exp , \mathrm{i}} \cdot \mathrm{k}_{\text {pos }, \text { unexp }, \mathrm{i}}+\Delta \mathrm{t}_{\mathrm{i}}\right) \cdot \mathrm{k}_{\mathrm{j}, \mathrm{i}} \\
& \mathrm{t}_{\text {ins }, \mathrm{i}}=\left(\mathrm{t}_{\text {ins }, 0, \mathrm{i}} \cdot \mathrm{k}_{\text {pos,exp }, \mathrm{i}}+\Delta \mathrm{t}_{\mathrm{i}}\right) \cdot \mathrm{k}_{\mathrm{j}, \mathrm{i}}
\end{aligned}
$$

with $t_{\text {prot, }, 0, i}$, basic protection value of layer $\mathrm{i}[\mathrm{min}] ; \mathrm{t}_{\mathrm{ins}, 0, \mathrm{i}}$, basic insulation value of layer $\mathrm{i}[\mathrm{min}] ; \Delta \mathrm{t}_{\mathrm{i}}$, correction time of layer $\mathrm{i}$ protected by gypsum plasterboards type F according to EN 520 [13] or gypsum fibreboards according to EN 15283-2

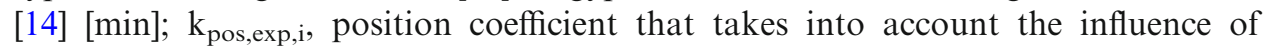

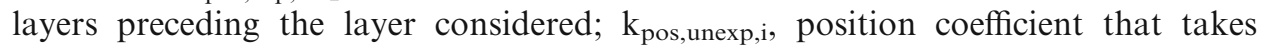
into account the influence of layers backing the layer considered; $\mathrm{k}_{\mathrm{j}, \mathrm{i}}$, joint coefficient.

The coefficients of the design method (basic times $t_{p r o t, 0, i}$ and $t_{i n s, 0, i}$, correction time $\Delta \mathrm{t}_{\mathrm{i}}$ as well as position coefficients $\mathrm{k}_{\mathrm{pos}, \mathrm{exp}, \mathrm{i}}$ and $\left.\mathrm{k}_{\mathrm{pos} \text {,unexp, }}\right)$ were calculated by extensive FE thermal simulations based on physical models for the heat transfer through separating multiple layered construction [15]. The material properties used for the FE thermal simulations were calibrated by fire tests performed on unloaded specimens at the EMPA, Dübendorf, using ISO fire exposure and validated by additional fire tests.

The basic insulation value $t_{\text {ins, } 0}$ corresponds to the fire resistance of a single layer without the influence of adjacent materials, i.e. according to EN 1995-1-2 the average temperature rise over the whole of the non-exposed surface is limited to $140 \mathrm{~K}$, and the maximum temperature rise at any point of that surface does not exceed $180 \mathrm{~K}$ for tests under ISO fire exposure (see Figure 1). The temperature of the layer at the beginning of the fire on the fire-exposed side as well as on the fire-unexposed side is assumed as $20^{\circ} \mathrm{C}$. The basic insulation value can be assessed by tests according to e.g. EN 1363-1 [16].

Wall and floor assemblies consisting of a single layer are only of limited application in timber assemblies. Most constructions consist of assemblies having two or 


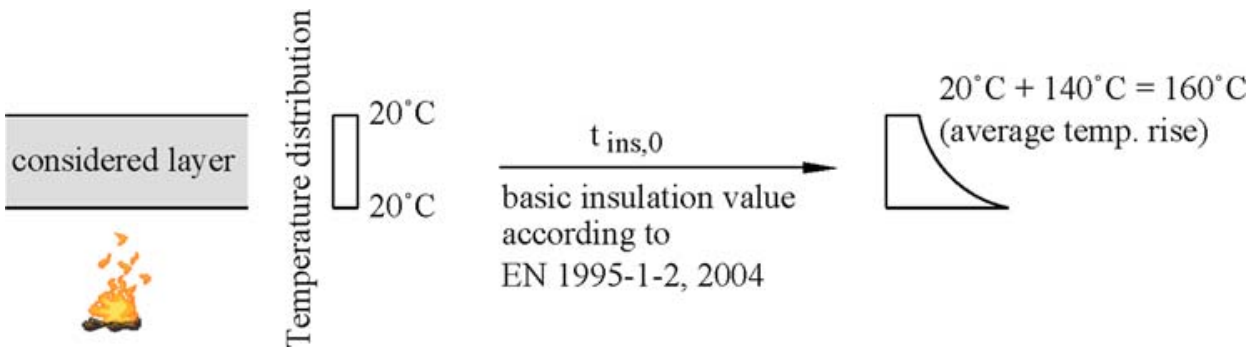

\section{Figure 1. Definition of the basic insulation value tins,o according to EN 1995-1-2 (the average temperature rise over the whole of the non-exposed surface is limited to $140 \mathrm{~K}$ ).}

more layers. The contribution of the each preceding layer to the separating function of the construction is mainly the protection of the backing layers. Therefore, it seems more appropriate to introduce a basic protection value $t_{\text {prot, } 0}$ defined as the time until failure of the fire protection in analogy to the calculation for the fire protective cladding of load-bearing timber constructions according to EN 13501-2 [17]. The testing method for fire protective cladding according to EN 13501-2 is performed with a particleboard of thickness $19 \mathrm{~mm}$ backing the layer under consideration. The contribution to the fire protection of this cladding may be assumed to be satisfied where the average temperature rise over the whole exposed surface of the particleboard is limited to $250 \mathrm{~K}$, and the maximum temperature rise at any point of that surface does not exceed $270 \mathrm{~K}$. Analogous to EN 13501-2, the definition of the basic protection value $t_{\text {prot }, 0}$ is illustrated in Figure 2.

The joint coefficient $\mathrm{k}_{\mathrm{j}}$ considers the joint details and their influence on the protection and insulation values of layers with joints. The position coefficient considers the position of the layer within the assembly (in direction of the heat flux), because the layers preceding and backing the layer have an influence on its fire behaviour. The position coefficient $\mathrm{k}_{\text {pos,exp }}$ takes into account the influence of the layers preceding the layer under consideration, while the influence of the layer backing this layer is considered by $\mathrm{k}_{\text {pos,unexp }}$. The position coefficients $\mathrm{k}_{\text {pos,exp }}$ were

$19 \mathrm{~mm}$ particleboard
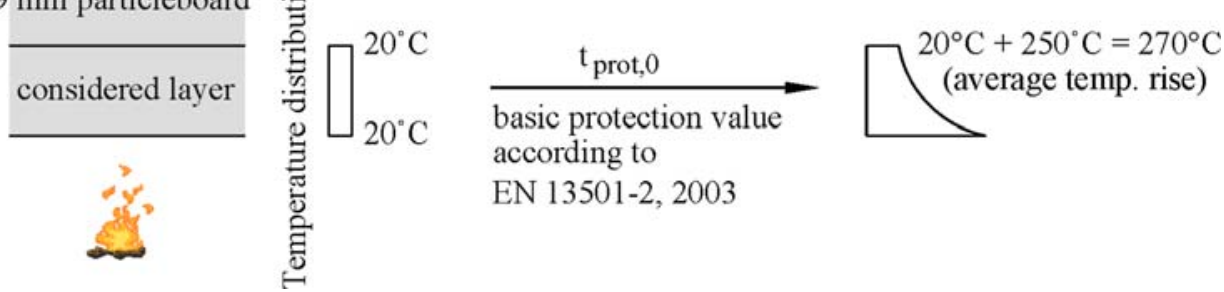
according to

EN 13501-2, 2003

Figure 2. Definition of the basic protection value tprot,o according to EN 13501-2 [17] (the average temperature rise over the whole of the exposed surface of the particleboard is limited to $250 \mathrm{~K}$ ). 
calculated by extensive FE thermal simulations assuming that the layers fall off when the temperature of $270^{\circ} \mathrm{C}$ is reached on the fire-unexposed side of the layers. Fire tests showed that this assumption is conservative for gypsum plasterboards of type F according to EN 520 [13] or gypsum fibreboards according to EN 15283-2 [14]. Therefore the protection or insulation values of layers protected by gypsum plasterboards type $\mathrm{F}$ or gypsum fibreboards can be increased by using a correction time $\Delta \mathrm{t}_{\mathrm{i}}$.

In the following the main results of experimental and numerical analyses as well as the calculation of the basic values $t_{\text {prot }, 0}$ and $t_{i n s, 0}$ for gypsum boards are described and discussed. The position and joint coefficients as well as the correction time $\Delta \mathrm{t}_{\mathrm{i}}$ are not the subject of this paper.

\section{Fire Tests}

A series of 17 small-scale fire tests (in the following mentioned as V1 to V17) was performed with non-loaded specimens using cladding made of gypsum or timber subjected to ISO fire exposure [4]. The fire tests were carried out in the EMPA's horizontal small furnace with the internal dimensions of $1.0 \times 0.8 \mathrm{~m}$. The objective of the fire tests was to provide fundamental experimental data on the thermal behaviour of cladding with regard to basic values $\left(t_{\text {prot }, 0}\right.$ and $\left.t_{\text {ins }, 0}\right)$ as well as the influence of layers backing or preceding the cladding under consideration. Thus, small-scale fire tests with non-loaded specimens were performed, some of them only with one single cladding layer. The mechanical behaviour of the cladding (e.g. falling off of the cladding) was not the subject of the fire tests carried out.

Gypsum plasterboards of type A and F according to EN 520 as well as gypsum fibreboards according to EN 15283-2 from three different European manufacturers were studied (see Table 1). Gypsum plasterboards of type A are regular common boards and contain a porous gypsum core with no reinforcement except the paper-laminated surface. Gypsum plasterboards of type $\mathrm{F}$ have improved core cohesion at high temperatures by adding other materials to the core such as glass fibres and fillers. Gypsum plasterboards of type $\mathrm{X}$ commonly used in North America also have improved core cohesion at high temperatures and may be

\section{Table 1 \\ Thickness and Mean Density of the Gypsum Boards Tested Under ISO Fire Exposure}

\begin{tabular}{lllr}
\hline Manufacturer & \multicolumn{1}{c}{ Type } & Thickness tested (mm) & Density $\left(\mathrm{kg} / \mathrm{m}^{3}\right)$ \\
\hline Manufacturer 1 & Gypsum fibreboard (GF) & $10,12.5,15,18$ & 1186 \\
Manufacturer 2 & Gypsum plasterboard (GP) of type A & 15 & 908 \\
& Gypsum plasterboard (GP) of type F & 15 & 853 \\
Manufacturer 3 & Gypsum fibreboard (GF) & 12.5 & 1504 \\
& Gypsum plasterboard (GP) of type A & $10,12.5,15,25$ & 810 \\
& Gypsum plasterboard (GP) of type F & 15 & 889 \\
\hline
\end{tabular}


considered similar to gypsum plasterboards of type F. Gypsum fibreboards have a gypsum core reinforced with paper fibres. Gypsum fibreboards usually have a higher density in comparison to gypsum plasterboards of type $\mathrm{A}$ and $\mathrm{F}$ (see Table 1) and may even exhibit a better fire performance than gypsum plasterboards of type $\mathrm{F}[18]$.

In addition to the different types of gypsum boards tested, the number, thickness and position of the boards as well as the cavity insulation have been varied. Usually, four different claddings were studied in each test (see Figure 3). A fire test with four identical gypsum boards showed the same temperature development for each cladding. Therefore the position of the claddings in the furnace did not influence the temperature development. During the tests the temperature at selected locations was measured using thermocouples of type K. For each cladding the thermocouples were placed on the fire-unexposed side as well as between cladding and timber frame (see Figure 4). All details of the fire tests can be found in [12].

Figure 5a shows the temperature development on the fire-unexposed side of gypsum fibreboards with different thickness. During heating the free and chemically bound water in the gypsum gradually evaporates at temperatures above $100^{\circ} \mathrm{C}$. This causes a temperature plateau on the fire-unexposed side of the boards, which is the main reason for the fire protective function of gypsum boards used as cladding. The duration of this plateau depends on the water content in the board and therefore on the thickness of the board.

(a)
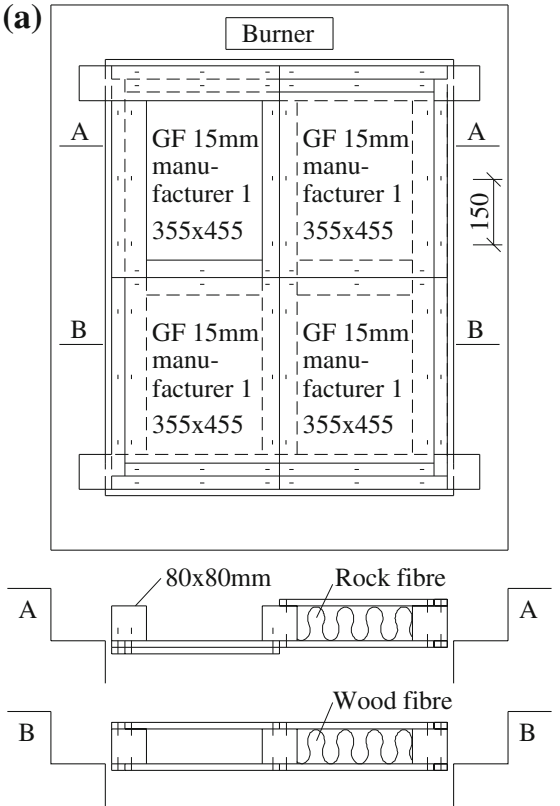

(b)

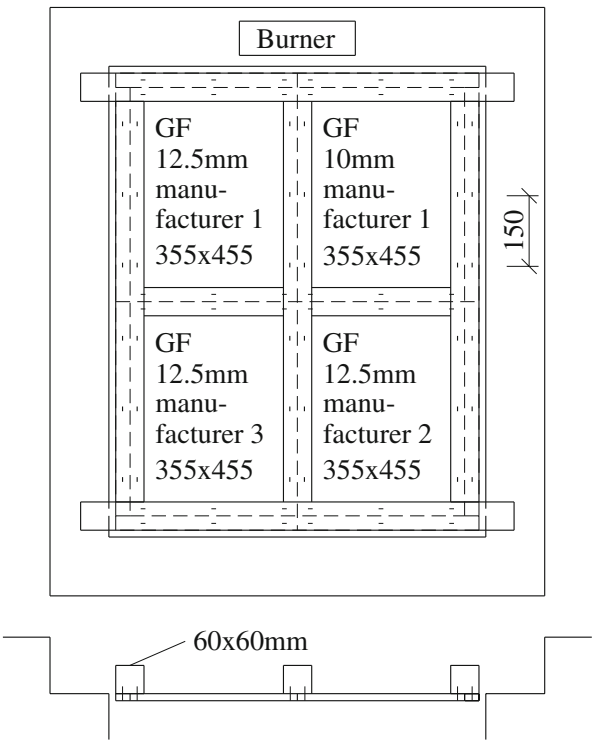

Figure 3. Test specimens for the small-scale fire tests: test specimen V4 (a) and V5 (b). 

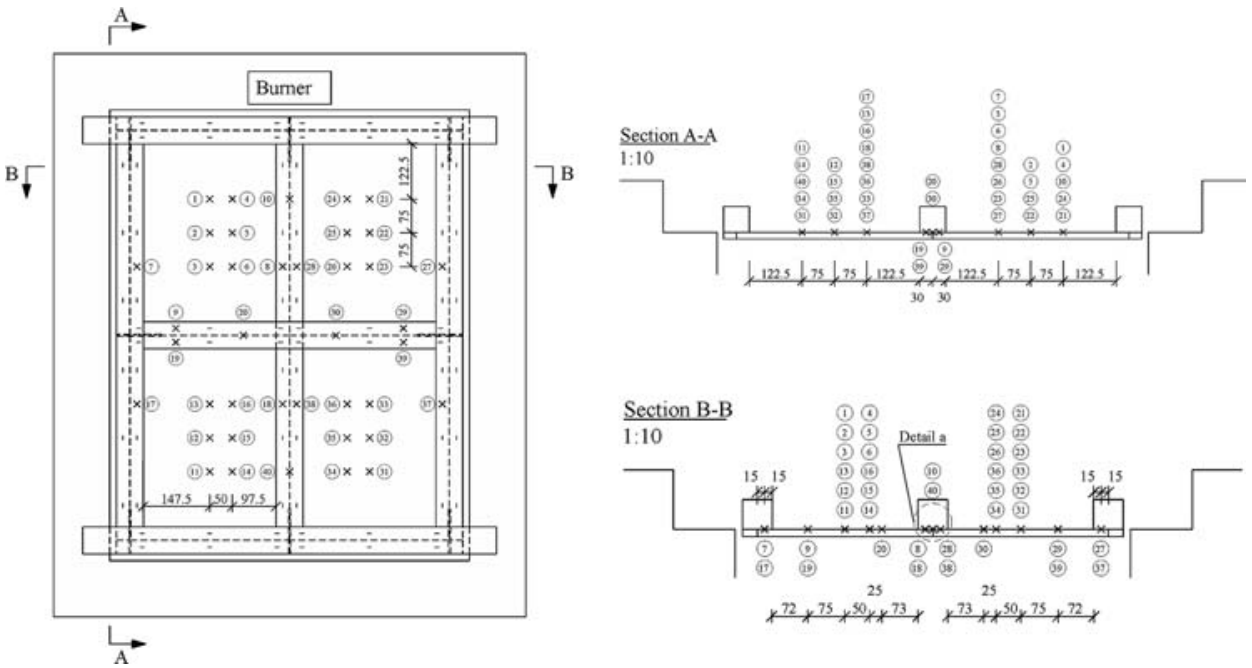

Figure 4. Position of thermocouples placed on the fire-unexposed side as well as between cladding and timber frame for test specimen V2.

(a)

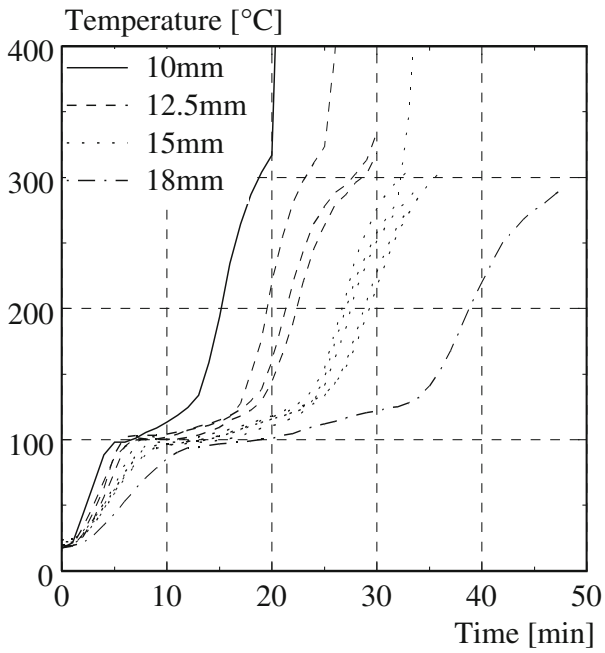

(b)

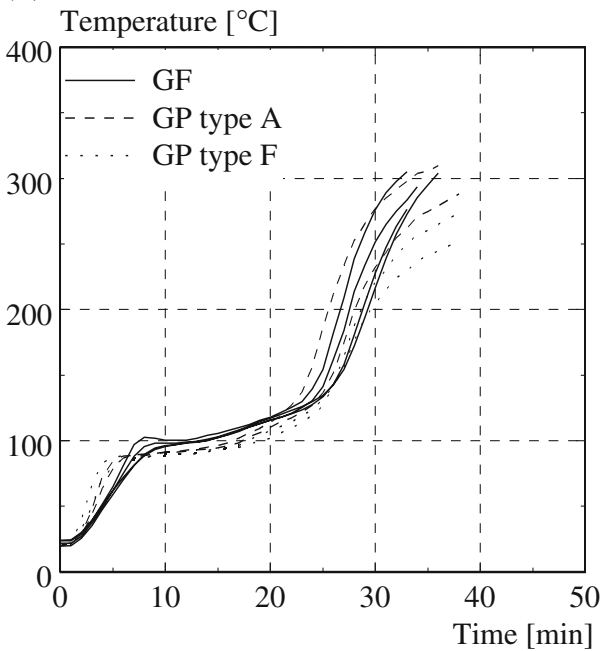

Figure 5. (a) Temperature development on the fire-unexposed side of gypsum fibreboards of different thickness tested as a single board; (b) temperature development on the fire-unexposed side of different types of $15 \mathrm{~mm}$ thick gypsum boards tested as a single board.

Figure $5 \mathrm{~b}$ shows the temperature development on the fire-unexposed side for different types of gypsum boards (gypsum plasterboards of type A and F as well as gypsum fibreboards) of the same thickness $(15 \mathrm{~mm})$. Even though gypsum 
boards of different type and manufacturer (with different density, fibres and fillers) were tested, the duration of the plateau at about $100^{\circ} \mathrm{C}$ was more or less the same and the overall temperature development measured up to about $200^{\circ} \mathrm{C}$ was quite similar (the differences in time for the same temperature measured were less than $5 \mathrm{~min}$ ). Thus, it can be assumed that the water content and therefore of gypsum for the different boards was about the same. Further, the addition of fibres and fillers to the gypsum core did not change significantly the thermal behaviour of the boards. However, the reinforcement of the gypsum core with fibres and fillers generally improves the stability and the mechanical properties (shrinkage, cracking, ablation, falling off) of the boards after complete dehydration. Noticeable is that the density of the gypsum fibreboards was much higher than for the gypsum plasterboards (see Table 1), but no significant difference was observed with regard to the thermal behaviour. Thus, the density does not seem to be a relevant parameter to describe the thermal behaviour of gypsum boards. The main parameter is the water content and therefore the thickness of the board (see Figure 5a). Fire tests conducted with regular gypsum plasterboards as well as gypsum plasterboards with improved core cohesion from different countries (Sweden, Canada, USA, New Zealand and Japan) and tested as fire protective cladding for a wooden member showed similar results [19]. The density of the boards tested varied between 651 and $864 \mathrm{~kg} / \mathrm{m}^{3}$.

All results shown in Figure 5 were obtained by testing single gypsum boards directly exposed to fire. In this way the thermal behaviour of the gypsum boards was studied without the influence of additional layers. However, gypsum boards used as cladding for light timber frame assemblies are usually backed by other boards (gypsum, timber), insulation batts (rock, glass or wood fibre) or void cavities. Figure 6a shows the temperatures measured for the small-scale fire test V4 with $15 \mathrm{~mm}$ thick gypsum fibreboards (see Figure 3a), which permitted the analysis of the influence of the void cavity or cavities filled with different insulation $(\mathrm{RF}=$ rock fibre, $\mathrm{WF}=$ wood fibre $)$ as well as the influence of multiple layers. Further, Figure 6a also shows the temperature development of $15 \mathrm{~mm}$ thick gypsum fibreboards tested as single board (fire test V2, see Figure 4). It can be seen that the temperatures measured behind the fire-exposed gypsum fibreboards for the assemblies with the cavities filled with rock fibre or wood fibre (see thermocouples T25 and T35) were similar and increased faster than for gypsum fibreboards tested as a single board (see T10). Additional fire tests with gypsum boards backed with glass fibre showed the same thermal behaviour as for gypsum boards backed with rock fibre or wood fibre. Thus, insulating batts caused the fireexposed gypsum boards to heat up more rapidly. The temperature development measured behind the fire-exposed gypsum fibreboard for the assembly with void cavity (see T15) followed up to $250^{\circ} \mathrm{C}$ roughly the same development as for gypsum boards backed with rock fibre or wood fibre (see T25 and T35). Subsequently, the temperature increase was slower. For the assembly with a double layer of $15 \mathrm{~mm}$ thick gypsum fibreboards, the temperature development measured behind the first gypsum fibreboard (see T5) followed up to $250^{\circ} \mathrm{C}$ roughly the same development as for gypsum fibreboards tested as single board (see T10). But then the temperature increase was slower. A possible reason may be the effect of 
(a)

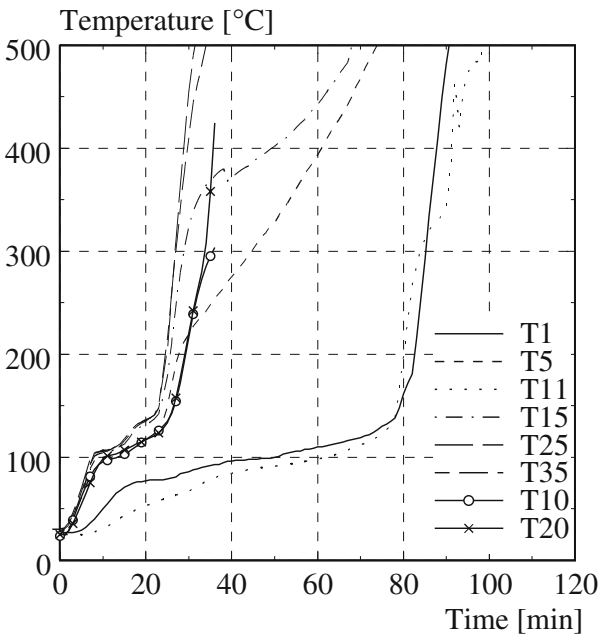

(b)

Position of thermocouples of fire test V4
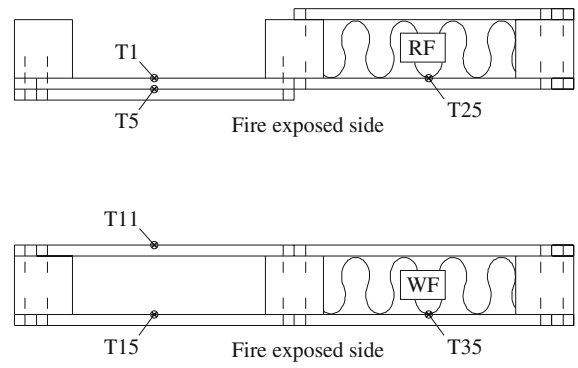

Position of thermocouples of fire test V2

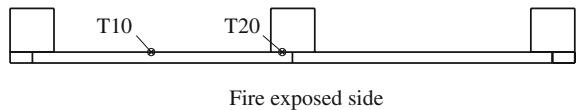

\section{Figure 6. (a) Temperature development for the small-scale fire test V4 (see Figure 3a) and V2 (see Figure 4); (b) position of the thermo- couples ( $R F=$ rock fibre, WF = wood fibre).}

some moisture migration from the second gypsum board towards the first gypsum board. Noticeable is that the temperature measured behind the fire-unexposed gypsum fibreboard for the assemblies with a void cavity and double layer (see T1 and T11) were quite similar. Thus, the void cavity did not influence significantly the temperature development on the fire-unexposed side of the assembly.

Temperature measurements between gypsum board and timber frame (see for example thermocouple T20 in Figure 6) as well as additional results of fire tests with gypsum boards backed by timber boards (OSB, particle boards) showed that the timber had a small influence on the thermal behaviour of the gypsum boards in comparison to gypsum boards tested as a single board (see also thermocouples T10 and T20 in Figure 6). Figure 7 summarizes the measured time taken to reach the temperature rise of $250^{\circ} \mathrm{C}$ (average) and $270^{\circ} \mathrm{C}$ (at any point) on the fire-unexposed side of $15 \mathrm{~mm}$ thick gypsum fibreboards tested as a single board or backed with different materials.

Table 2 summarizes the measured fire resistance of the small-scale fire tests V4 and V9 with regard to the insulation criterion. According to most standards (e.g. EN 13501-2) the insulation failure is the time taken for the average temperature on the fire-unexposed side of the whole construction to increase by $140^{\circ} \mathrm{C}$ and at any point by $180^{\circ} \mathrm{C}$. It can be seen that assemblies with cavities filled with rock fibre batts showed the highest fire resistance although the thermal behaviour of gypsum boards backed by insulating batts is influenced unfavourable (see Figsures 6,7). The shortest fire resistance was measured for the assembly consisting of 3 layers of gypsum fibreboards, although the total thickness of the gypsum fibreboards was the same as for the other assemblies given in Table 2. The main 


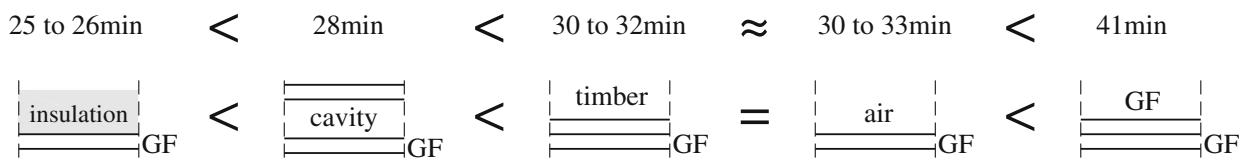

\section{Figure 7. Time taken to reach the temperature rise of $250^{\circ} \mathrm{C}$ (average) and $270^{\circ} \mathrm{C}$ (at any point) on the fire-unexposed side of $15 \mathrm{~mm}$ thick gypsum fibreboards tested as a single board or backed with different materials.}

\section{Table 2}

Measured Fire Resistance of the Small-Scale Tests V4 and V9 with Regard to the Insulation Criterion (Temperature Rise Criteria: $140^{\circ} \mathrm{C}$ / $180^{\circ} \mathrm{C}$ at Unexposed Side of Assembly)

\begin{tabular}{l} 
Fire test \\
\hline V9 \\
V4 $10+10+10 \mathrm{~mm}$ gypsum fibreboards
\end{tabular}

reason is that the $10 \mathrm{~mm}$ thick gypsum fibreboards fell off sooner than the $15 \mathrm{~mm}$ thick gypsum fibreboards. Noticeable is that the insulation time of the assembly with the cavity filled with $80 \mathrm{~mm}$ thick wood fibre batt was lower than for the assembly with a void cavity. The reason was that first the wood fibre batt caused the fire-exposed gypsum board to heat more rapidly, and secondly the wood fibre batt started to shrink strongly when directly exposed to fire and fell off. Unlike 
the wood fibre batt, the rock fibre batt remained in place during the whole time of fire exposure.

\section{FE Thermal Analysis}

For the calculation of the temperature development in gypsum boards subjected to an ISO fire a FE thermal analysis was conducted using ANSYS. The heat transfer to the surface of the member was calculated using temperature-independent constant values according to EN 1991-1-2 [20] for the resultant emissivity by radiation $\varepsilon_{\text {res }}=0.8$ and the coefficient of heat transfer by convection $\alpha_{\mathrm{c}, \exp }=25 \mathrm{~W} / \mathrm{m}^{2} \mathrm{~K}$ and $\alpha_{\mathrm{c} \text {,unexp }}=4 \mathrm{~W} / \mathrm{m}^{2} \mathrm{~K}$. Density, thermal conductivity and specific heat capacity of gypsum vary as a function of temperature. Unfortunately, the thermal properties of gypsum at high temperatures are difficult to measure. Transient effects and the method of measurement can have a significant effect on the test results [21]. Further, the thermal properties are influenced by mass transfer of moisture into or out of the gypsum board as well as cracking and ablation. In order to consider these effects the thermal properties are usually calibrated with results of fire tests. Thus, thermal properties of gypsum used in FE thermal analyses are often "apparent" values rather than "real" physically correct material properties and explain the large scatter of values used by different authors [22].

For this study the variation of density with increasing temperature was determined by a thermo gravimetric analysis (TGA) carried out at the Institute for Geotechnical Engineering of ETH Zurich. The analysis was carried out at a heating rate of $20^{\circ} \mathrm{C} / \mathrm{min}$ using a piece of gypsum board of type A used for the tests. The TGA showed an initial mass loss of about $17 \%$ between 100 and $170^{\circ} \mathrm{C}$ and a second mass loss of about $5 \%$ between 600 and $750^{\circ} \mathrm{C}$ and agreed well with results of other studies (see Figure 8a) [23-25]. Further, the gases emitted during the TGA were measured. Between 100 and $170^{\circ} \mathrm{C}$ water vapour $\left(\mathrm{H}_{2} \mathrm{O}\right)$ was measured and between 600 and $750^{\circ} \mathrm{C}$ carbon dioxide $\left(\mathrm{CO}_{2}\right)$. Figure $8 \mathrm{~b}$ compares the temperature-dependent density used for the FE thermal analysis with values assumed by other authors.

Gypsum boards mainly consist of gypsum, a crystalline form of calcium sulphate combined with water known as calcium sulphate dihydrate $\left(\mathrm{CaSO}_{4} \cdot 2 \mathrm{H}_{2} \mathrm{O}\right)$. When exposed to increasing temperature calcium sulphate dihydrate undergoes two endothermic decomposition reactions in which the chemical bound water is removed leading to calcium sulphate anhydrite $\left(\mathrm{CaSO}_{4}\right)$. In addition to calcium sulphate dihydrate, gypsum board contains other materials in various quantities depending on the manufacturer. For example, the results of the TGA in combination with an additional analysis with a Roentgen diffractometer showed that the gypsum board tested consisted of more than $80 \%$ gypsum, about $10 \%$ calcium magnesium carbonate $\left(\mathrm{CaMg}\left(\mathrm{CO}_{3}\right)_{2}\right)$ and the remaining $10 \%$ was poorly indentified additional materials. A similar composition of a different gypsum board was found in [25].

Figure 9 shows the temperature-dependent specific heat used for the FE thermal analysis. In the figure values measured and assumed by other authors are also given. The variation of the specific heat as a function of the temperature was cal- 
(a)

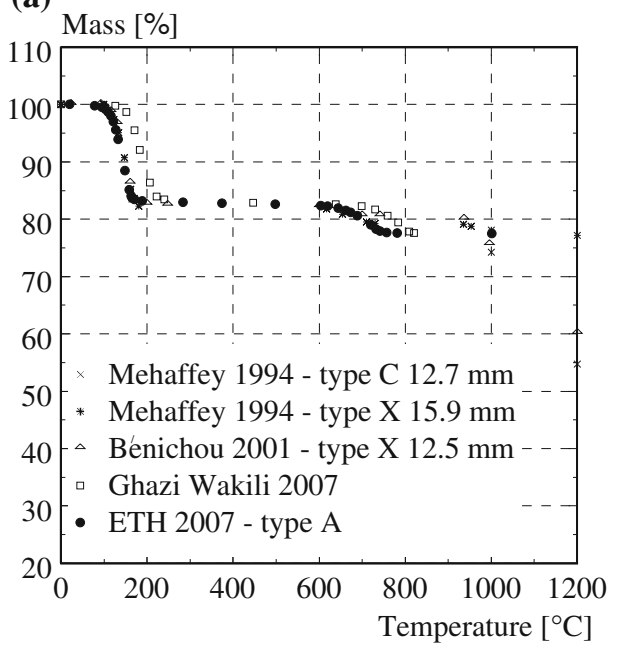

(b)

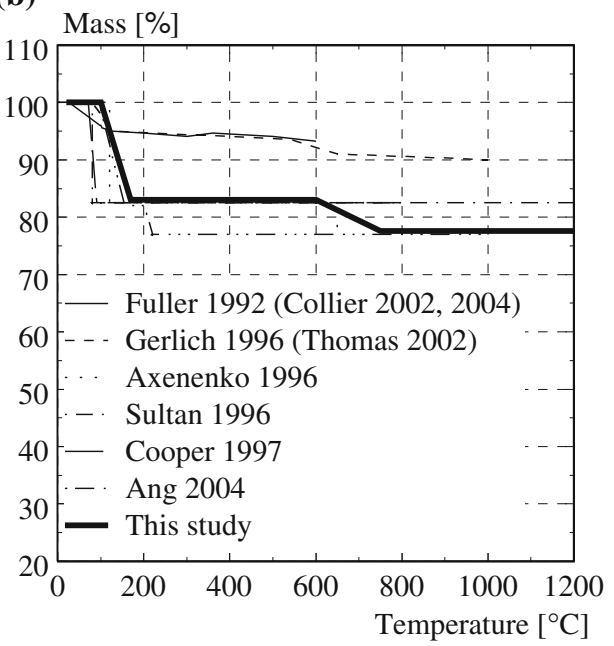

\section{Figure 8. (a) Mass loss with increasing temperature measured by thermo gravimetric analysis conducted by different authors; (b) Temperature-dependent density used for the FE thermal analysis in this study as well as in previous studies.}

culated taking into account the different chemical reactions occurring during the heating of gypsum boards. The first peak in Figure 9 represents the two endothermic reactions of the dehydration of gypsum as mentioned earlier. Based on the TGA results it was assumed that both reactions occurred between 100 and $170^{\circ} \mathrm{C}$. The first peak was assumed by all authors, however, the total energy may differ depending on the total amount of free and chemical bound water assumed in the gypsum board or because of model calibration. The second peak represents the decomposition of the calcium magnesium carbonate. Based on the TGA results it was assumed that this reaction occurred between 600 and $750^{\circ} \mathrm{C}$. Although the second peak strongly differed from the values assumed by other authors, its influence on the temperature development is not so relevant, as the chemical reaction occurs at elevated temperature and the reaction enthalpy is relative small.

The thermal conductivity was assumed based on measurements found in the literature $[23,24,26]$ and calibrated to results of fire tests with single gypsum plasterboards. The value of the thermal conductivity assumed between 20 and $70^{\circ} \mathrm{C}$, which is higher in comparison to values assumed by other authors, takes into account the increased heat transfer due to mass transfer of moisture. Shrinkage, cracks and ablation of gypsum boards increase the heat flux due to radiation and convection. For simplicity, these effects were modelled by increasing the thermal conductivity starting from $600^{\circ} \mathrm{C}$. This approach has already been used by other authors. Figure 10 shows the temperature-dependent thermal conductivity used for the FE thermal analysis. In the figure values measured and assumed by other authors are also given. 


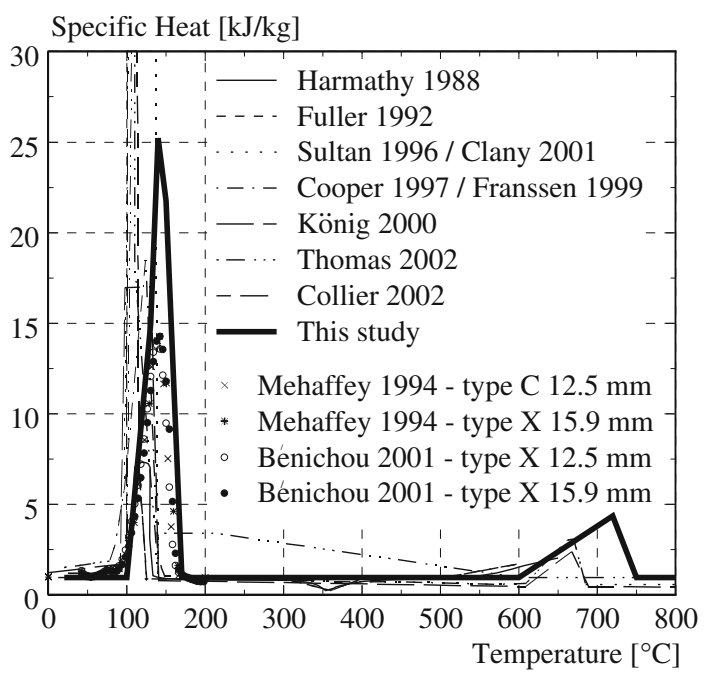

\section{Figure 9. Temperature-dependent specific heat used for the FE ther- mal analysis in this study as well as in previous studies. The points given in the figure indicate measured values of the specific heat.}

The results of 12 small-scale fire tests on single gypsum boards were used to calibrate the material properties assumed for the FE thermal analysis (FEA). In this way, the thermal behaviour of the gypsum boards was not influenced by other layers. Figure 11a compares the results of the FE thermal analysis with the results of the small-scale fire tests on single gypsum boards. The FE thermal analysis predicted the temperature development of the gypsum boards with a thickness of 10 , 12.5 and $15 \mathrm{~mm}$ satisfactorily. For the gypsum board with a thickness of $18 \mathrm{~mm}$ the increase of the temperature after complete dehydration based on the FE thermal analysis occurred about 5 minutes earlier than in comparison to the fire test, i.e. the result of the FE thermal analysis was conservative. After calibration with the fire tests on single gypsum boards, the material properties were verified with additional 15 small-scale and large-scale fire tests [27-29]. For example, Figure $11 \mathrm{~b}$ shows the comparison between FE thermal analysis and fire tests on gypsum boards backed by timber board or particleboards. It can be seen that the FE thermal analysis also predicted the temperature development of gypsum boards satisfactorily. Additional detailed comparisons between FE thermal analysis and fire tests can be found in [15].

\section{Basic Values of Gypsum Boards}

Based on the FE thermal analysis Equation (4) was developed for the calculation of the basic protection value $t_{\text {prot }, 0}$ of gypsum boards, where $t_{\text {prot }, 0}$ was calculated 


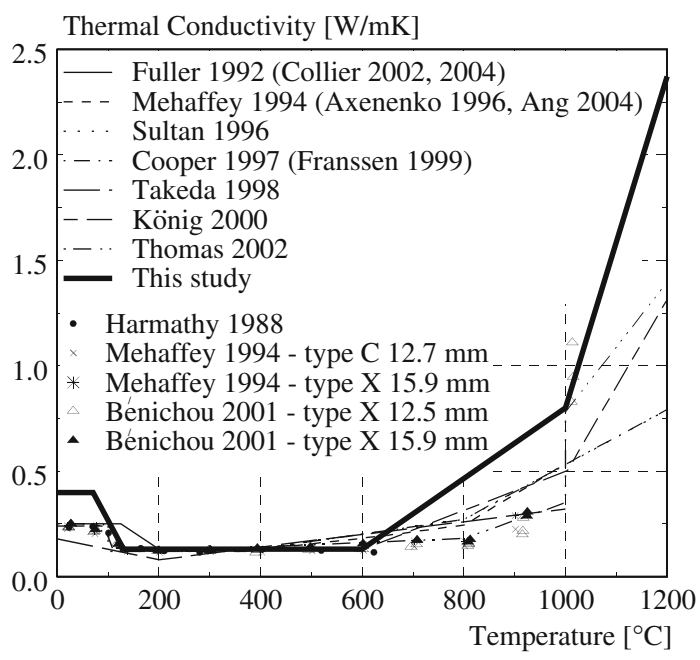

Figure 10. Temperature-dependent thermal conductivity used for the FE thermal analysis in this study as well as in previous studies. The points given in the figure indicate measured values of the thermal conductivity.
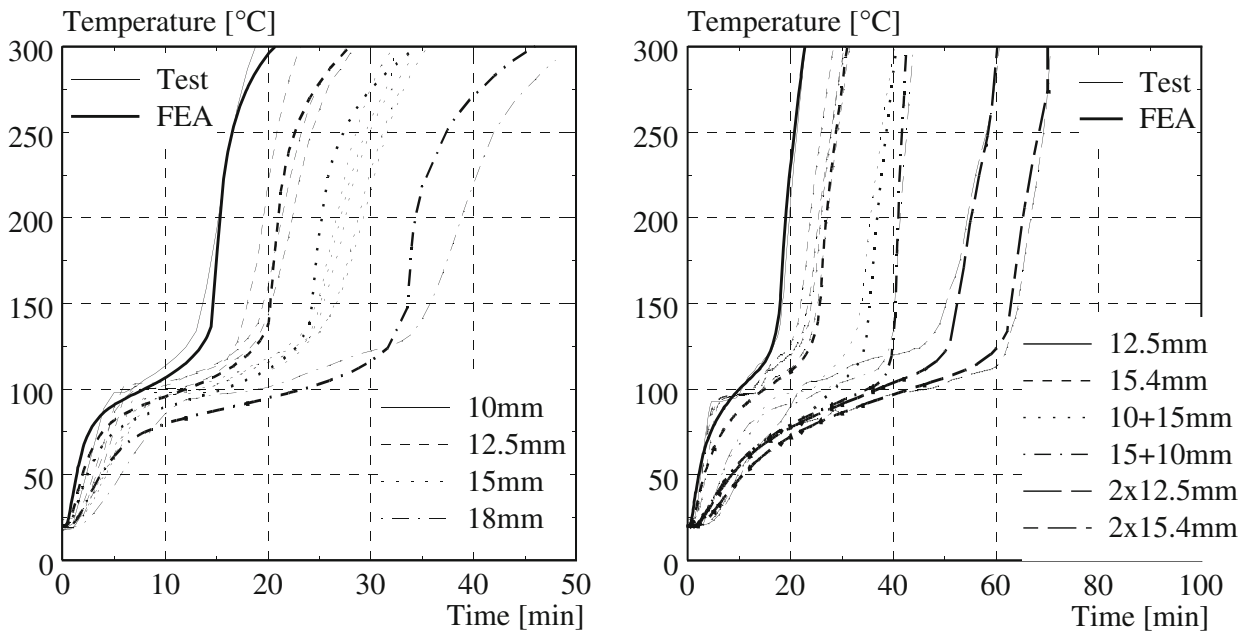

Figure 11 . Comparison between measured and calculated temperatures for different fire tests.

in analogy to the testing method for fire protective claddings given in EN 13501-2, i.e. considering single gypsum boards backed by a $19 \mathrm{~mm}$ thick particleboard (see Figure 2). 


$$
\mathrm{t}_{\mathrm{prot}, 0}=30 \cdot\left(\frac{\mathrm{h}_{\mathrm{p}}}{\mathrm{h}_{\mathrm{p}, \mathrm{ref}}}\right)^{1.2}[\mathrm{~min}]
$$

where $h_{p}$ is the thickness in mm of the gypsum board and $h_{p, r e f}$ is the thickness of a reference gypsum board $\left(\mathrm{h}_{\mathrm{p}, \mathrm{ref}}=15 \mathrm{~mm}\right)$.

EN 1995-1-2 gives rules for the calculation of the start of charring of timber surfaces protected by fire protective claddings made of wood-based panels or wood panelling as well as gypsum plasterboards. Thus, the start of charring has the same significance as the basic protection value $t_{\text {prot }, 0}$. For claddings consisting of one layer of gypsum plasterboard of type A or F the time of the start of charring $t_{\text {ch }}$ can be calculated as:

$$
\mathrm{t}_{\mathrm{ch}}=2.8 \cdot \mathrm{h}_{\mathrm{p}}-14[\mathrm{~min}]
$$

where $h_{p}$ is the thickness in mm of the gypsum plasterboard. EN 1995-1-2 assumes a linear correlation between thickness of the board and the start of charring. Equation (5) is based on fire tests with solid timber protected by the gypsum boards [19]. Further, it was assumed that the solid timber protected by the gypsum board started charring when the temperature between gypsum and particleboard reached the temperature of $300^{\circ} \mathrm{C}$.

Figure 12 shows the comparison of Equations (4) and (5) with all results of the small-scale fire tests performed with gypsum boards backed by timber board or frame. It can be seen that the difference between Equations (4) and (5) is quite small and both agree well with the test results. Unlike EN 1995-1-2 Equation (4) assumes a non-linear relationship between thickness of the board and the basic protection value.

The FE thermal analysis permitted the development of Equation (6) for the calculation of the basic insulation value $t_{\text {ins }, 0}$ of gypsum boards. The basic insulation value $t_{\text {ins }, 0}$ was calculated assuming a single gypsum board and considering the criterion of $140^{\circ} \mathrm{C}$ for the increase of the temperature on the fire-unexposed side of the board (see Figure 1).

$$
\mathrm{t}_{\text {ins }, 0}=24 \cdot\left(\frac{\mathrm{h}_{\mathrm{p}}}{\mathrm{h}_{\mathrm{p}, \mathrm{ref}}}\right)^{1.4}[\mathrm{~min}]
$$

where $h_{p}$ is the thickness in mm of the gypsum board and $h_{p, r e f}$ is the thickness of a reference gypsum board $\left(\mathrm{h}_{\mathrm{p}, \mathrm{ref}}=15 \mathrm{~mm}\right)$.

EN 1995-1-2 gives following equation for the calculation of the basic insulation value $t_{\text {ins }, 0}$ of gypsum plasterboards of type $A$ and $F$ :

$$
\mathrm{t}_{\text {ins }, 0}=1.4 \cdot \mathrm{h}_{\mathrm{p}}[\mathrm{min}]
$$

where $h_{p}$ is the thickness in mm of the gypsum plasterboard. Like Equation (5) EN 1995-1-2 assumes a linear correlation between thickness of the board and the basic insulation value. 


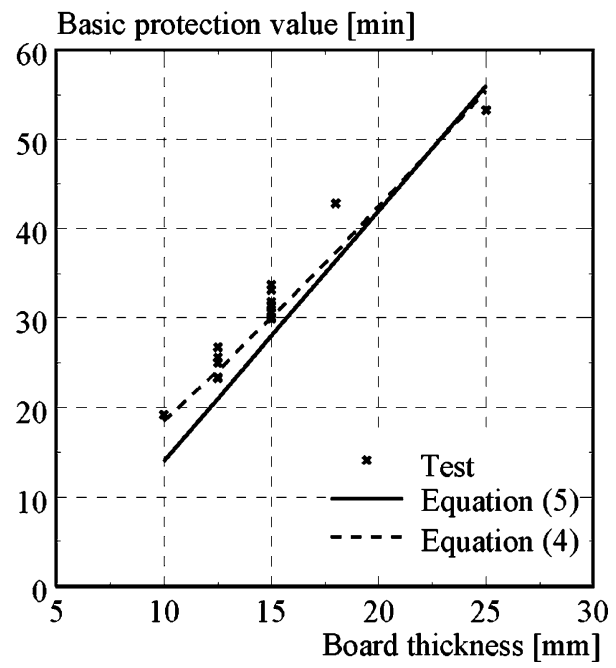

\section{Figure 12. Comparison of Equations (4) and (5) with all results of the small-scale fire tests performed with gypsum boards backed by timber board or frame.}

Figure 13 shows the comparison of the basic insulation value measured in the small-scale fire tests and calculated according to Equations (6) and (7) for all fire tests with gypsum boards tested as a single board. It can be seen that the basic insulation values calculated according to Equation (7) (EN 1995-1-2) were in a good agreement only with the results of fire tests with $10 \mathrm{~mm}$ thick gypsum boards. By increasing the thickness of the board the basic insulation values were underestimated, i.e. Equation (7) led to conservative results. Vice versa, the results based on the FE parametric study (Equation (6)) agreed better with the test results. Unlike EN 1995-1-2 Equation (6) assumes a non-linear relationship between thickness of the board and the basic insulation value.

\section{Conclusions}

The fire behaviour of gypsum boards was investigated by means of a large number of small-scale fire tests. In order to study the thermal behaviour of the gypsum boards without the influence of additional layers some fire tests were performed using single boards. The fire tests showed that the overall thermal behaviour of different types of gypsum board (with different density, fibres and fillers) was quite similar. Thus, the reinforcement of the gypsum core did not influence significantly the thermal behaviour, but generally improved the mechanical properties (shrinkage, cracking, ablation, falling off) of the boards after complete dehydration. Further, the test results showed that the layer backing the gypsum board may have a strong influence on the thermal behaviour of the gypsum board. Insulating batts caused the fire exposed gypsum boards to heat more 


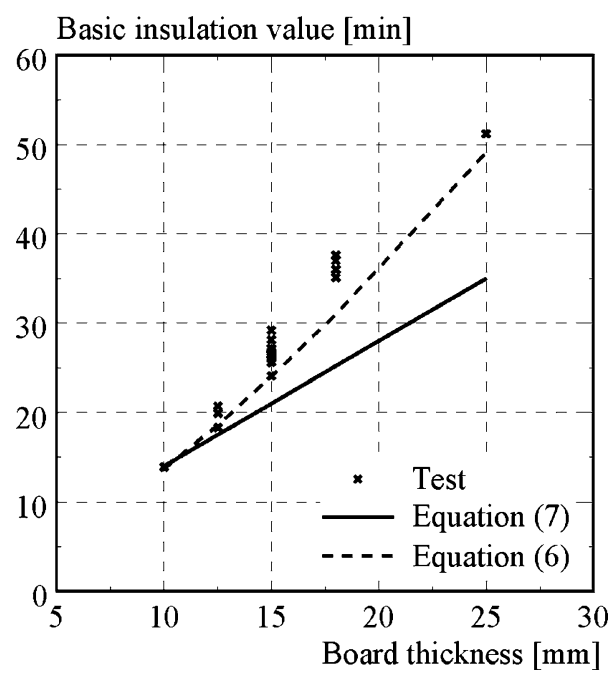

Figure 13. Comparison of basic insulation value measured in the fire
tests and calculated according to Equations $(6)$ and $(7)$ for all gypsum
boards tested as single board.

rapidly and fail sooner. However, assemblies with cavities filled with insulating batts that remained in place after failure of the cladding showed the highest fire resistance with regard to the insulation criterion. The temperature development in gypsum boards subjected to ISO fire exposure was simulated with an FE thermal analysis. The material properties assumed for the FE thermal analysis were calibrated with results of several fire tests on single gypsum boards and verified with additional small-scale and large-scale fire tests. A FE parametric study permitted the development of new equations for the calculation of the basic protection value as well as the basic insulation value of gypsum boards. The new equations were in better agreement with fire test results in comparison with the equations given in EN 1995-1-2.

\section{References}

1. Takeda H, Mehaffey JR (1998) WALL2D: a model for predicting heat transfer through wood-stud walls exposed to fire. Fire Mater 22:133-140. doi:10.1002/(SICI)10991018(1998070)22:4<133::AID-FAM642>3.0.CO;2-L

2. König J, Walleij L (2000) Timber frame assemblies exposed to standard and parametric fires, Part 2: a design model for standard fire exposure. Trätek, Report I 0001001, Stockholm

3. Young SA, Clancy P (2001) Structural modelling of light-timber framed walls in fire. Fire Saf J 36:241-268. doi:10.1016/S0379-7112(00)00053-9

4. ISO 834-1 (1999) Fire-resistance tests-Elements of building construction-Part 1: General requirements 
5. König J, Oksanen T, Towler K (2000) A review of component additive methods used for the determination of fire resistance of separating light timber frame construction. In: International council for research and innovation in building and construction, working commission W18 - Timber structures. Delft, Netherlands, CIB-W18/33-16-2

6. British Standard BS 5268-4 (1990) Structural use of timber-Sect. 4.2. Recommendations for calculating fire resistance of timber stud walls and joisted floor constructions, BSI

7. National Building Code of Canada NBCC (2005) Volume 2, Canadian Commission on Building and Fire Codes. Institute for Research in Construction, National Research Council of Canada, Ottawa, Canada

8. Norén J (1994) Additionsmetoden-Beräkning av brandmotstånd hos avskiljande väggar (Addition method - Calculation of fire resistance for separating wood frame walls), Trätek-Swedish Institute for Wood Technology Research. Report I:9312070

9. Östman B, König J, Norén J (1994) Contribution to fire resistance of timber frame assemblies by means of fire protective boards. In: Proceedings of the $3 \mathrm{rd}$ international fire and materials conference, Washington DC, USA

10. ENV 1995-1-2, Eurocode 5 (1994) Design of timber structures, Part 1-2: General rules-Structural fire design. CEN, Brussels

11. EN 1995-1-2, Eurocode 5 (2004) Design of timber structures, Part 1-2 General rules-Structural fire design. CEN, Brussels

12. Schleifer V, Frangi A, Fontana M (2007) Experimentelle Untersuchungen zum Brandverhalten von Plattenelementen. Institute of Structural Engineering, ETH Zürich, IBK Report No. 302

13. EN 520 (2004) Gypsum plasterboards, definitions, requirements and test methods. CEN, Brussels

14. EN 15283-2 (2008) Gypsum boards with fibrous reinforcement-Definitions, requirements and test methods-Part 2: Gypsum fibre boards. CEN, Brussels

15. Schleifer V (2009) Zum Verhalten von raumabschliessenden mehrschichtigen Holzbauteilen im Brandfall. PhD Thesis ETH No. 18156, ETH Zurich

16. EN 1363-1 (1999) Fire resistance tests, Part 1: General requirements. CEN, Brussels

17. EN 13501-2 (2003) Fire classification of construction products and building elements Part 2: Classification using data from fire resistance tests, excluding ventilation services. CEN, Brussels

18. Kordina K, Meyer-Ottens C (1995) Holz Brandschutz Handbuch. Deutsche Gesellschaft für Holzforschung e.V. Ernst \& Sohn Verlag, München

19. Tsantaridis LD, Östman B, König J (1999) Fire protection of wood by different gypsum plasterboards. Fire Mater 23:45-48. doi:10.1002/(SICI)1099-1018(199901/02)23:1<45:: AID-FAM662 > 3.0.CO;2-6

20. EN 1991-1-2 Eurocode 1 (2002) Actions on Structures-Part 1-2: General actionsActions on structures exposed to fire. CEN, Brussels

21. Thomas G (2002) Thermal properties of gypsum plasterboards at high temperatures. Fire Mater 26:37-45. doi:10.1002/fam.786

22. Källsner B, König J (2000) Thermal and mechanical properties of timber and some other materials used in light timber frame construction. In: International council for research and innovation in building and construction, Working Commission W18-Timber Structures. Delft, Netherlands, CIB-W18/33-16-3

23. Mehaffey JR, Cuerrier P, Carisse G (1994) A model for predicting heat transfer through gypsum-boards/woos-stud walls exposed to fire. Fire Mater 18:297-305. doi:10. 1002/fam.810180505 
24. Bénichou N, Sultan MA, MacCallum C, Hum J (2001) Thermal properties of wood, gypsum and insulation at elevated temperatures. NRCC, Internal Report IR-710, Ottawa

25. Wakili GK, Hugi E, Wullschleger L, Frank T (2007) Gypsum board in fire-Modeling and experimental validation. J Fire Sci 25:267-282. doi:10.1177/0734904107072883

26. Harmathy TZ (1988) Properties of building materials. The SFPE handbook of fire protection engineering, society of fire protection engineers, 2nd edn. National Fire Protection Association, Boston

27. König J, Norén J (1997) Timber frame assemblies exposed to standard and parametric fires-Part 1: Fire tests. Trätek, Rapport I 9702015, Stockholm

28. König J, Walleij L (1999) One-dimensional charring of timber exposed to standard and parametric fires in initially unprotected and post-protection situation. Trätek, Rapport I 9908029, Stockholm

29. König J, Rydholm D (2003) Small-scale fire tests of heavy timber components. Trätek, Rapport P 0310036, Stockholm 